\title{
Challenges in the delivery of 'Urban Villages' through complex stakeholder partnerships, and multi-discipline approaches: Achieving cohesive built form at Kelvin Grove Urban Village in Australia, and Melrose Arch in South Africa
}

Paul S. Sanders

School of Design, Creative Industries Faculty, Queensland University of Technology, Australia

\begin{abstract}
The ontological perspective of cities is that from settlement they are the product of incremental growth with a major variable being the size and speed of development. Historically, cities are characterised as having growth which is evidenced by mostly organic urban patterns exhibiting a patina of diverse urban forms that reflect its longevity. The accumulation of the incremental development of such cities results in the manifestation of fine grain spatial complexities. Planned cities on the other hand, whether of colonial settlement or utopian ideal, have mostly been based on geometrical footprints. In these types of cities the rapid changes to the built environment inflicted by post-industrialised societies has exerted severe pressure on their urban form. The advent of the 'Urban Village' in the latter part of the twentieth century was conceptualised on the goal for 'humane, sustainable and mixed use urban living' in response to the predicament of the sterile new urban developments of the mid twentieth century. This paper discusses the conceptual background of urban villages through the application of a case study of Kelvin Grove Urban Village in Brisbane, Australia, and examines the principal challenges of achieving a high-level of architectural cohesion in urban form as demonstrated in the approach taken at Melrose Arch in Johannesburg, South Africa. The combined findings of the two case studies suggest that a multi-disciplinary approach to the design of complex urban precincts through sophisticated planning is crucial to the successful 'stitching' of urban villages into their surroundings.
\end{abstract}

KEYWORDS: Urban Villages, urban form, stakeholder partnerships, multi-discipline 


\section{INTRODUCTION}

The perpetual deliberation on the appropriate form required of modern architecture to produce cohesive urban forms raises the fundamental issues of how architects, planners and decision makers can enhance what is known to 'work', and 'repair the traumatised building tissue in historic city centres' (Cataldi, 2003) caused by developments that have not heeded the fundamental behavioural rules of urban form that affects a building's context in design and history.

Urban morphology has emerged as a discipline with established research methods that enables analytical practice on various aspects of the built from of cities. It is from evaluation and assessment of a cities morphology that a better understanding of its origins and evolution can be developed, from which esoteric dimensions such as meaning can be deduced. The epistemological basis of cities therefore suggests the need to interpret the historical evidence of urban morphology, in order for a complete understanding of the specificity of a place that is rooted in the genius loci. Furthermore, the understanding that the 'historical unfolding of the built environment is the starting point in the search for a theoretical basis for the management of urban landscapes in the future' (Whitehand, 1992).

When design guides for individual buildings are produced they concentrate on design details and are often 'unaware of the way that the deeper structuring levels, especially street layout or plot configuration, affect settlement form' (McGlynn and Samuels, 2000). Talen and Ellis (2002) on the other hand have concern that the city will 'codify and institutionalise a particular regime of 'totalising" order' in that a building environment stifled by over prescriptive design controls may also be counter-productive. Effective models of urban design are therefore required in order to guarantee the successful outcomes of major urban developments as the norm rather than exception.
Urban Villages grew in popularity as a result of attitudes to a variety of problems associated with the traditional 'downtown', and as an alternative to a low density sprawling suburbia, that was lacking a sense of community, convenience, and sophisticated urban lifestyle (Gupta et al., 2008). Urban villages are 'distinct social and spatial areas' (Bell and Jayne, 2004) that are planned or institutionally developed to 'appeal to the consumption practices of the emerging professional, managerial and service classes' (Bell and Jayne, 2004). This paper will examine two urban developments that demonstrate a sophisticated approach to the creation of engaging urban places based on traditional urban street layouts that were achieved through a combination of multi-stakeholder partnerships, and multi-disciplinary collaboration.

\section{URBAN VILLAGES}

The Urban Village as a conscious approach to new planned neighbourhoods is synonymous with the notion of a 'village in the town' (Murray, 2004) but is differentiated from the terminology of a 'village in the city' (Yan, 2008; Uehara, 2008) that relates to existing communities, sometimes rural, that have been 'consumed' in the enveloping urban form of rapidly expanding metropoles.

The Urban Village Forum (UVF), established in the UK in 1995, published a report that identified six key tenets; an Urban Village should be: a) small, neighbourhood size; b) combine residential with work, retail and leisure units; c) aim to be self-sustaining; d) mix different social and economic groups; e) have efficient transport and be well designed; and be f), well managed (Murray, 2004). An Urban village is a 'dense, self-sustaining, walkable community that has a strong residential component and includes a combination of retail, dining, leisure, and commercial uses - in short, a compact development in which people can live, work and play' (Gupta et al., 2008). 
The Urban Land Institute have articulated ten development principles for successful urban villages, these are:

1. Create an enduring public realm (a compelling central place as a focus and public events, highly visible and accessible, people places of streets and open spaces surrounded by fine buildings);

2. Respect market realities (type and size of retail, spending capacity of surrounding population);

3. Share the risk; share the reward (partnership of public and private interests, engage citizens of the community, challenge planning and zoning controls that may be too inflexible);

4. Plan for development and financial complexity (financing and ownership issues, phasing strategies, longer pre-development periods, higher overall risk);

5. Integrate multiple uses (mixture of uses, livework- play concept, create lively pedestrian experience, resolve diverse parking demands);

6. Balance flexibility with a long-term vision (considerations of building design, block size, and infrastructure location to support future flexibility);

7. Capture the benefits that density offers (walkable neighbourhoods, housing choice and affordability, transportation choices, improved security, protect the environment);

8. Connect to the community (active, occupied and well maintained sidewalks/pavements that are retail friendly with a sense of permanence);

9. Invest for sustainability (factor the local climate, water conservation, optimise systems);

10. Commit to intensive on-site management and programming (public activities and events). (Gupta et al., 2008).
These ten development principles capture the salient progressive attributes that are required to guide good project management of new urban developments, as will be tested in the case study examples later in the paper.

Murray (2004) suggests several further important factors for improvement of future approaches to Urban Villages that includes: Cultural planning, multidisciplinary approaches to creative neighbourhoods as central to the success of the whole city, legislation for localised control of developments, and community ownership of space. Additionally, the social mix in Urban Villages is an essential component of their blueprint, but requires careful consideration in its planning and development. It is the breaking up of the monofunctional building typologies, such as: retail, supermarket, office, residential, and educational; and integrating these into a mixed use development that offers the potential for a vibrant urban domain. Murrain (1993) argues for the need for a 'robust' building form as an essential part of the 'recipe' for a mixed use town, buildings that are resilient over time and can adapt to changing needs of its changing utilisation, as a solution to both planning and social challenges (Murray, 2004).

New Urbanists advocated for a 'design- oriented approach' to new development (Berke, 2002) through Form Based Zoning guidelines seeking to regulate the form of the built environment 'without regards to use' (Hecimovich, 2004). In contrast, conventional town planning primarily aims to control land use and density, but is largely silent on matters of form. Nevertheless, the successes and shortcomings of New Urbanism are to be found in how historical models of 'good urban form' have been appropriated and applied to new developments. While on the one hand urban space exemplars are an important source as an assured basis for new configurations, the propensity for imitative building aesthetics in many design codes disguises the appearance of traditional urban areas from the fundamental underlying urban 
formation and structure. An example is the Princes Foundation (organisation evolved from the UVF) that fixated its agenda on traditional forms of planning articulated through the overtly simplistic neo-classical aesthetics, this approach led to the establishment of the Prince of Wales Institute of Architecture in 1986, and built outcomes such as the vernacular replica suburbia of Poundsbury in the UK.

In Brisbane, large scale urban precincts have recently been developed under the label of 'Urban Villages'. Whether as a village within, or extension to the existing city, what parameters are necessary for urban design to guide the successful delivery of Urban Villages through multi-disciplinary contexts. The following section addresses these challenges though a case study of Kelvin Grove Urban Village.

\section{KELVIN GROVE URBAN VILLAGE: BRISBANE}

The Kelvin Grove Urban Village (KGUV), $2 \mathrm{~km}$ north-east of the city centre of Brisbane, is an exemplar of city making through the cooperative partnership and common purpose of government, university, and private enterprise to deliver an integrated and vibrant urban precinct that 'transforms a strategically positioned inner city area into a new residential, educational, and commercial address for Brisbane- one that is synonymous with knowledge, creativity and sustainability' (QUT, 2004).

An opportunity to utilise a large tract of redundant army barrack land was initiated by the Queensland Government Department of Housing (QDP) as a stimulus for the adjacent university campus of the Queensland University of Technology (QUT) to expand into a hybrid precinct of educational, commercial, retail, and public facilities and residential dwellings including affordable housing units (Woods, 2003: Byrne, 2013). The 16.5 hectare mixed use development envisioned a spatial framework that optimises physical, virtual and social links. The combined corporate objectives for an 'integrated university facilities with a range of housing types and commercial activities' (Wardner and Hefferan, 2015) centred on the creation of a new Creative Industries Precinct as the anchor facility providing the catalyst for a creative suburb and knowledge based urban development (Pancholi et al., 2015; Yigitcanlar et al., 2016). KGUV is a model for inner city sites and suburban areas (QUT, 2002), a unique creative community offering a knowledge network, lifestyle choice, and connected environment (QUT, 2004).

The vision for KGUV was founded on the necessity to embrace the increasing demands of choices for urban living to be based on the attributes of opportunity, innovation, creativity, authenticity and entrepreneurship (QUT, 2004). The desired urban life is for the intensity and activity for safe, friendly, walkable, and vibrant communities, and social objectives of mutual obligation and inclusion through the sharing of communal spaces (QUT, 2002). KGUV seeks to enhance the State's economic development through job creation and ecological sustainability. It is a focus on accessible urban outcomes that supports a primarily 'all day, and all year' public realm focused on a main street. The brief for the development underpins the vision and sets the specific goals of exemplary practice (QUT, 2002). The hopes for the precinct were to capture the global movement towards a live-work integrated environment based on established principles of: a quality natural environment; distinctive urban amenities; range of lifestyle preferences; presence of cultural and education institutions; 'hipness', tolerance and an entrepreneurial culture; and, good accessibility with a range of public transport services (QUT, 2004).

\section{Master-planning through complex stakeholder engagement}

The regional context of the project is specifically the proximity of QUT with a large population of students and staff, many of whom reside in Kelvin Grove. The main criteria established in 
the initial report for the development was broadly to achieve Environmentally Sustainable Development principles through the following objectives: 1) a primary linking street and entrance into the precinct between the main arterial road and QUT campus, with new Creative Industries Precinct highly visible at the new intersection; 2) provide a mix of uses along the main central street as the central focus; 3 ) provide residential uses to the periphery adjacent to existing residential areas; and, 4) provide residential uses throughout the site to activate public spaces including streets. The masterplan (see Figure 1) also sought to incorporate the best planning theories of Transport Orientated Development and Crime Prevention Through Environmental Design (Woods and Hammonds, 2002). Effective transportation is an important factor in the success of KGUV, with thoughtful integration of car, bicycle and pedestrian requirements. An open space system enhances the street network and connects the precinct with neighbouring parks, conserving the natural and cultural values of the site (QUT, 2002).

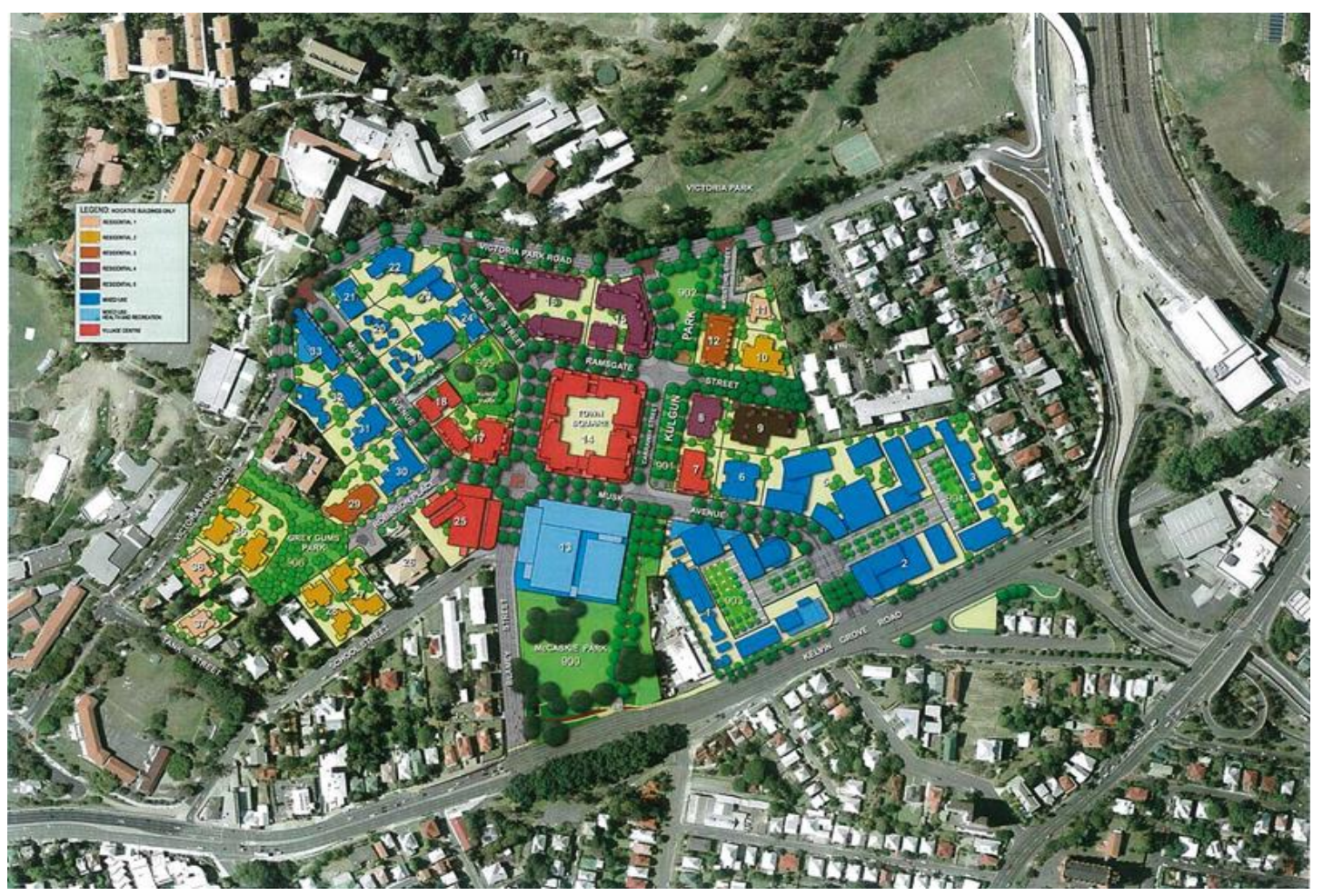

Figure 1. KGUV Original Land Use Plan 2001 (QUT, 2004). A town square is indicated in the courtyard space of the central perimeter block building, this was later changed to a semi-private space for the residential buildings, with the focus shifting to the adjacent main street intersection.

The subsequent approval of the report and development of a comprehensive masterplan and framework for delivery was led and produced by a multidisciplinary team that comprised: urban designers; town planners; a people and place consultant; a lawyer and urban optimist; and development and project managers. The masterplan was advanced during an intensive six-month program of workshops and consultation with the major stakeholders being: QUT; Government Departments of Housing and Transport; Brisbane City Council (BCC); Brisbane Housing Company; and, community representatives. The workshops 
aimed to reaffirm the core vision and objectives, and establish the relevant market proposition and implementation strategies that included planning for delivery, budget, and documentation (QUT, 2004). In particular, the QDH identified goals for the urban village to deliver a range of high quality affordable housing options integrated with main-stream private residential developments that showcased cost effective urban and architectural design, whilst promoting social equity and a strong community identity. Likewise, QUT identified influencing factors for the project as optimising teaching and learning environments that integrate with research, development and business enterprise through a practical demonstration of engaging with the wider community (QUT, 2004).

\section{Local Area Plan}

A Local Area Plan for the KGUV was developed for incorporation into the City Plan of the BCC, and is a performance based statutory control with principles for acceptable solutions for development of practical and affordable sustainable building outcomes within the village. All developments are required to submit a strategy that addresses compliance with sustainable principles for: energy efficiency, greenhouse gas reduction, water efficiency, waste recycling, and life cycle of materials. The incentive for individual developments which include sustainable measures is an entitlement to a $10 \%$ bonus of gross floor area (Woods and Hammonds, 2002) within a general range of 4 to 7 storey developments (BCC, 2000).

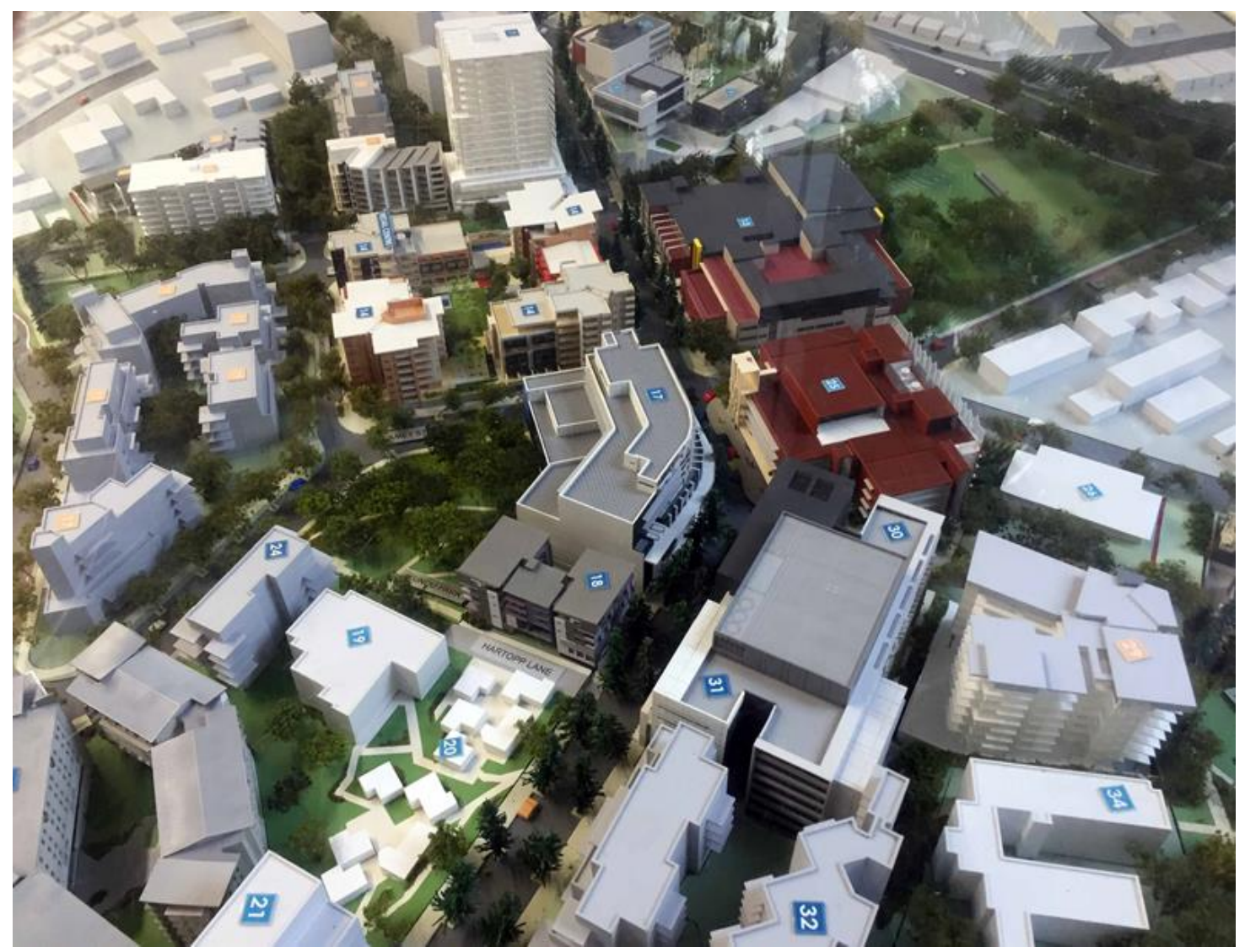

Figure 2. KGUV Precinct Model. The main high street is through the centre of the picture flanked by major educational, office and retail buildings. Residential buildings are predominantly at the precinct edges. (Source: Author). 


\section{Building Design}

It is through the design of building that the outcomes required of the Local Area Plan were to be delivered, advancing current best industry practice with regard to all elements of sustainable development. Minimum performance criteria of the design, construction, operation and life cycle maintenance were required to be met, with particular regard to: energy efficiency, transportation, biodiversity, atmospheric management, water management, indoor air quality management, waste management, and noise and light pollution (Woods and Hammonds, 2002). Although some consideration was made to engage a single large developer, a progressive decision was taken to subdivide the development into relatively small lots $\left(1000 m^{2}-2000 m^{2}\right)$ to encourage ' a more eclectic, human-scale design philosophy within the village and also to facilitate integrated and diverse land uses, including affordable and welfare housing' (Wardner and Hefferan, 2015).

The Building form and height of individual proposals was determined by the allocated gross floor area (GFA), and the intended transition from land use to development proposition was focused on the mix of uses across the site within a series of sub-precincts or 'character zones' (QUT, 2004). Despite prescriptive design parameters in terms of the relationship of buildings to streetscape (Wardner and Hefferan, 2015), a short-fall however existed in the lack of a detailed guide to each plot that could determine how the form of individual buildings from one site to another could be integrated and managed, as will be discussed further.

\section{Implementation}

KGUV had an excellent management team, made up of senior representatives of both QUT, the Department and key consultants who remained involved through practically the entire project and who enjoyed wide recognition and respect of the development and property community (Wardner and Hefferan, 2015, p.392)

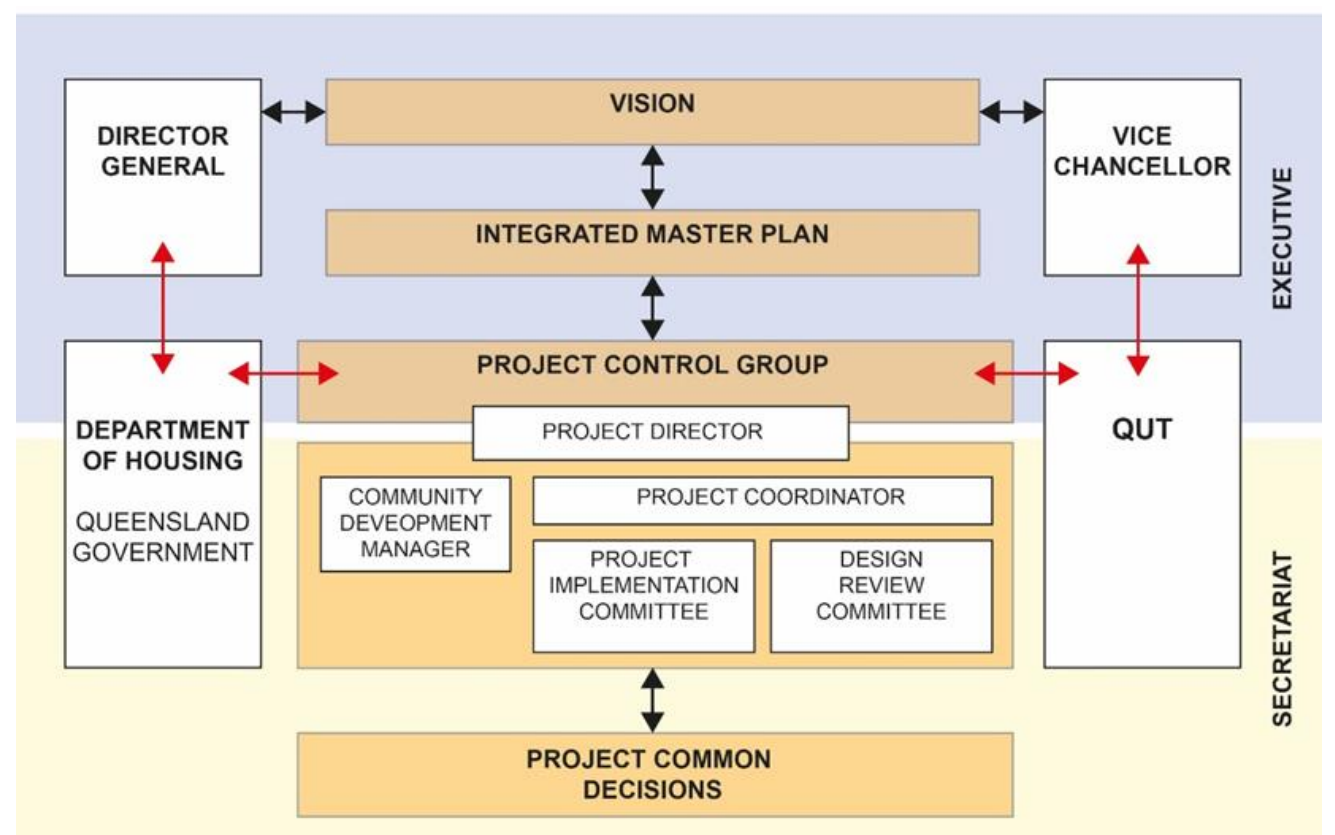

Figure 3. KGUV Governance structure and decision making model (Adapted from QUT, 2004). 
A Deed of Cooperation between QUT and QDH was implemented in 2001 and cemented the commitment of the major project participants to a governance model to guide the delivery of the project. The governance structure for the project involved multi-stakeholder representation through an executive level project control group with responsibility to drive the optimal outcomes for the project participants and ensure that the vision and ambition for KGUV was achieved (Figure 3). The Project Control Group (PCG) was the executive level body that had authority over the strategic direction of the project and directly facilitated the relationship between project participants (QUT, 2004).

The Secretariat comprises the Project Development Facilitator (Independent Chair of PCG) and Project Coordinator (operational responsibility for the site), Urban Design Manager (design quality control), and Community Development Manager (social, civic and community fabric/ identity/ spirit). Together this team asserted control over the implementation of the project though the function of a Project Implementation Committee. Finally, a design review committee was established to assess and monitor the quality, consistency and compliance of project proposals, ensuring that the design principles for KGUV are consistently applied (QUT, 2004).

\section{Outcomes}

Pancholi et al. (2015) surmise that KGUV achieves its design objectives through a range of attributes:

- Character, integration of culture and nature; People orientated-ness, human scale and pedestrian environment; Creative image through connectivity of lower floors to public spaces, use of public art; built character;

- Connectedness: Interconnected public spaces, integration of anchor project; public-private visual connections, internal events;

- Permeability: spatially, through mixed land uses; socially, through attention to locations heritage including indigenous values; economically, through public and private land ownership delivering a spectrum of housing affordability models; environmentally, through attention to architectural scale and sustainable design.

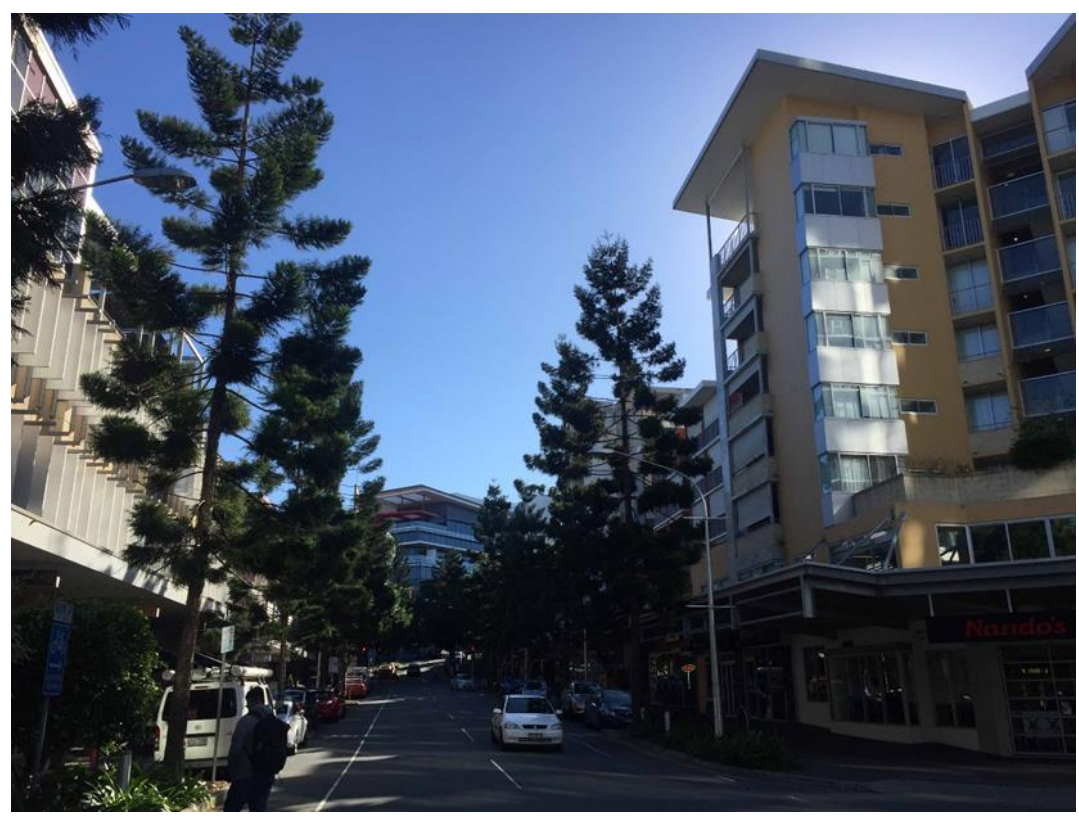

Figure 4. View along KGUV main high street (Source: Author). 
While all of the above can be evidenced, there are however some shortcomings in the final built outcome, 'Although some of its detail isn't what was asked or hoped for, the urban design essentials are there' (Byrne, 2013). One significant aspect is the change from the original Land Use Plan (QUT, 2004) that showed the central 'Town Square' (see Figure 1) located in the form of a pedestrian plaza enveloped by surrounding buildings, a global public space typology known for its attribute as a place of public gathering, event, and recreation. Disappointingly, this space has become an internal semi-private courtyard elevated above the retail and supermarket of the "Village Centre' building; there is no clearly identifiable central space other than the points of the main street intersections. Consequently, although there are open space provisions in the parks, and courtyard spaces of the Creative Industries' precinct, the lack of a central public square has bereft KGUV of a crucial spatial asset for precinct focus and community events.

Furthermore, the precinct lacks attention to the architectural resolution and integration between individual buildings. While design performance criteria that includes environmentally sustainable design principles have been met, the individual buildings are mostly disconnected from each-other with the architectural outcomes being mostly autonomous buildings, without a cohesive urban form that could be associated with village, town, or city. This raises a concern on the governance process of the individual development proposals, and the need for a rigorous assessment and management planning control process. While the Integrated Masterplan (QUT, 2004) states the required qualities through written commentary, it lacks detailed guidelines (form based codes) that the building designs are required to conform.

How both of these aspects could have been accomplished will be discussed further through the Melrose Arch example in the next section. Being of similar scale to KGUV, Melrose Arch demonstrates how autonomous buildings can be 'stitched' together through the guiding principles of a form based code, and a masterplan established on the principle of connective streets anchored by major public spaces.

\section{COHESIVE URBAN FORM AT MELROSE ARCH, JOHANNESBURG}

Melrose Arch is an 18 hectare major urban development project based on the principles of traditional urban form within a mixed use neighbourhood. It is one of the largest projects of its type in the Southern Hemisphere (Figure 4). The initiative was the result of the intervention of urbanist Paul Murrain in association with local urban designers, who skilfully guided the development that was originally destined to be another ubiquitous office park into a precinct based proposal defined by a series of perimeter urban blocks, with a central 'high street' connecting the two main urban squares.

Most importantly, the form design codes controlled the overall homogeneity of the urban precinct and simultaneously allowing individual buildings to have some autonomy in the design of materials and architectural features. It is this aspect that sets Melrose Arch apart. The high levels of collaboration of participating architects was unusual, great attention was made in how individual building projects would integrate alongside each-other, particularly with respect to facades that comprised the main streetscapes (Sanders, 2001; Hall and Sanders, 2011).

\section{Multi-disciplinarity}

A multi-disciplinary approach was undertaken in the first phase of the development. Each urban block had a separate project consultant team commissioned that consisted of quantity surveyors, engineers, and multiple architectural practices for the block clusters to ensure a high degree of design diversity and focus to the detail parts of the overall development. The architectural practices had been selected though 
an invited competition process that was adjudicated by an expert peer-review panel which not only ensured the quality of participating architects, but also the opportunity for small sized 'design orientated' practices to be appointed, where 'business-as-usual' would tend to see larger corporate architectural practices dominating the commissioning processes.

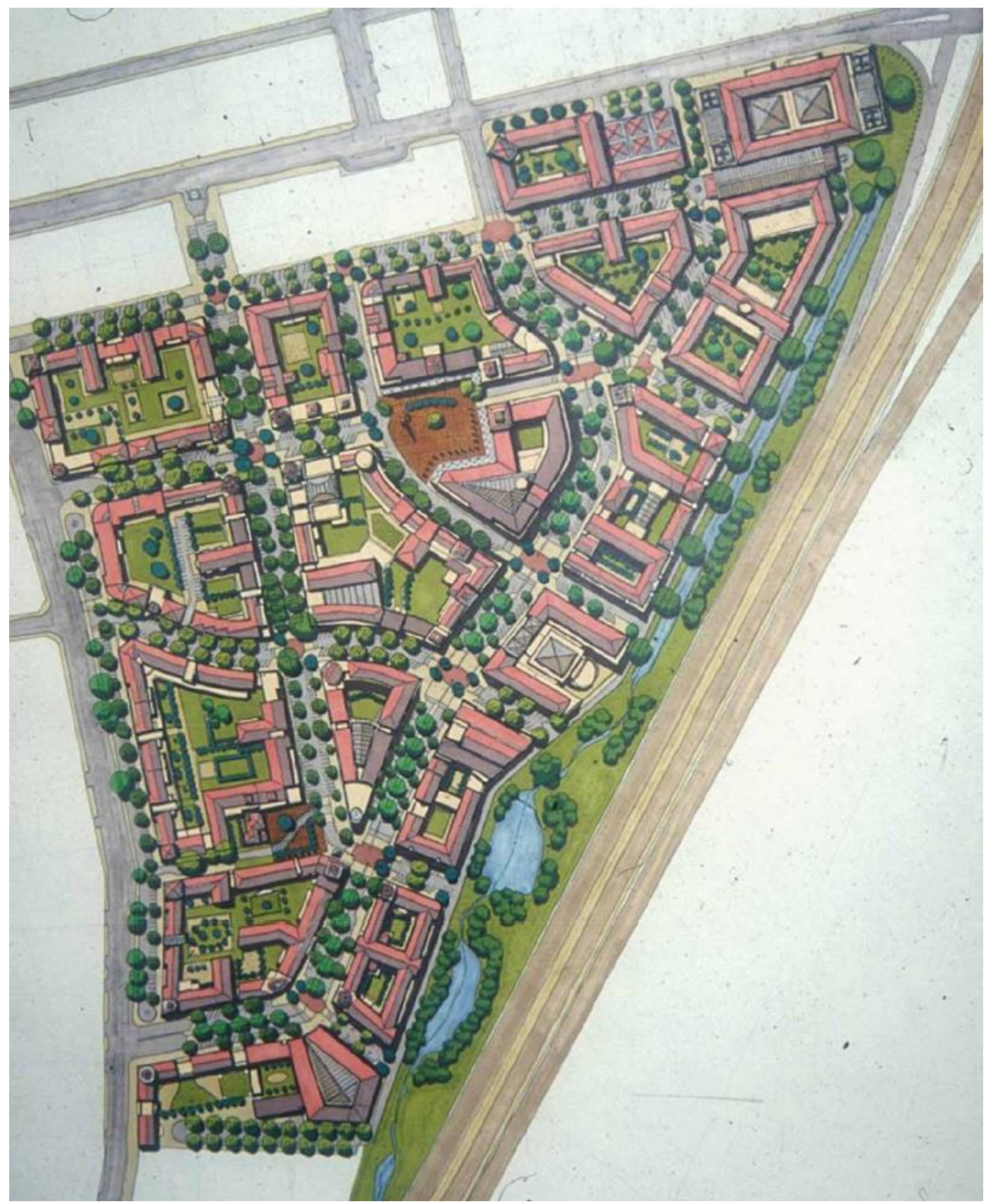

Figure 4. Melrose Arch Masterplan. Street system (connecting to primary local road network) and major public squares that both provide focus for retail, commercial and entertainment facilities as the catalyst for public life in the precinct (US and MAPPS). 
At the outset, the project consultants were engaged in a two-day 'retreat' for team building exercises that were aimed at shifting conventional attitudes to project development towards the innovative thinking that would be required of all consultants to capture the unique opportunities afforded by the project ambitions. Overall coordination was undertaken by the precinct urban designers with particular attention to the management and compliance in the process of building designs that included expert review sessions of the architecture.

\section{Design Guidelines}

The design guidelines, codes, and principles for Melrose Arch were developed to augment the masterplan for the precinct that were 'based on traditional town planning notion of mixed use, connectivity, an integrated open street system, and clearly defined public and private realms' (US and MAPPS, p1). Urban design objectives further substantiated the desire for urban forms that supported safe and secure 24-hour environments through development flexibility that could respond to changing market requirements.

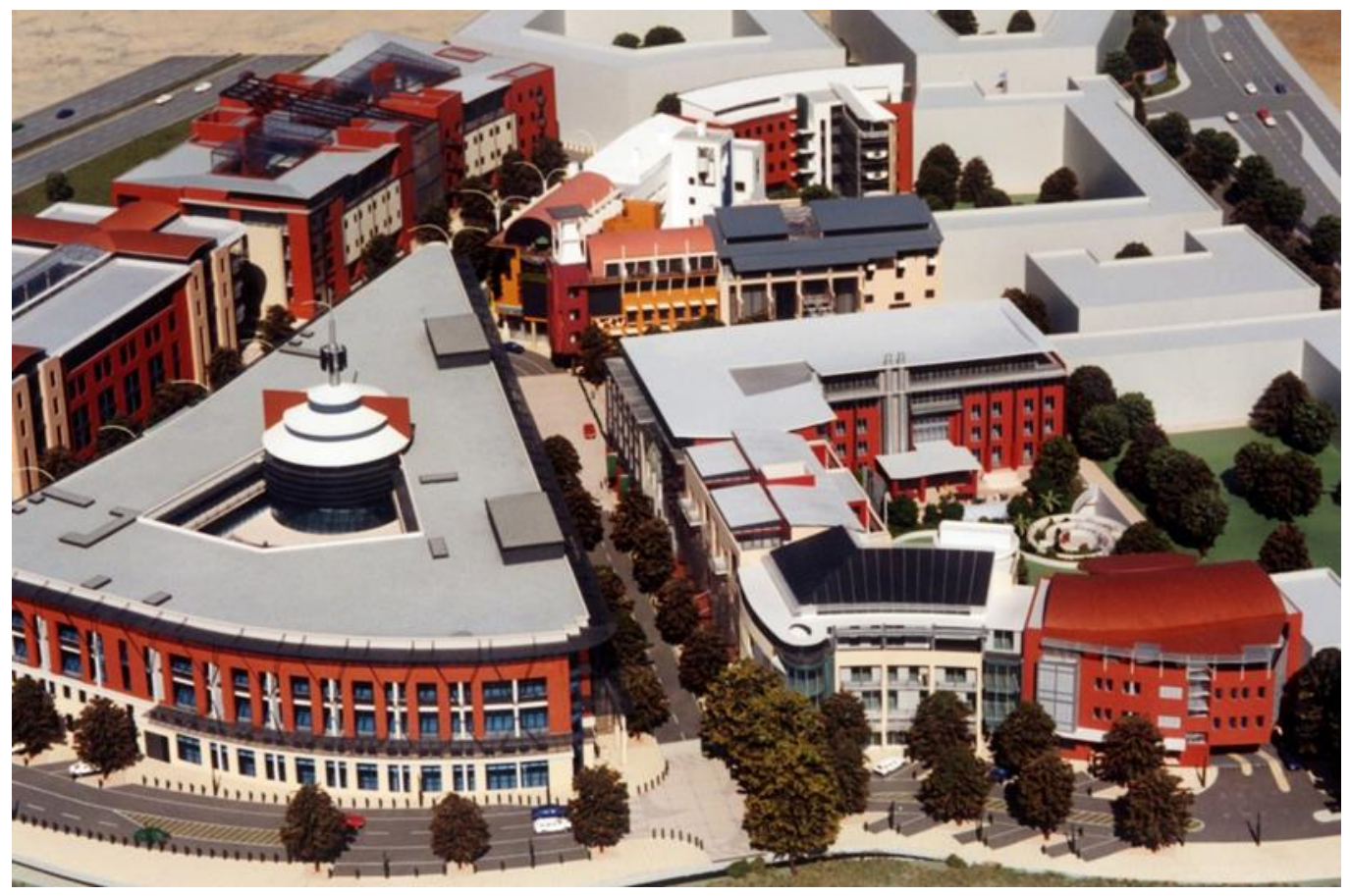

Figure 5. Melrose Arch Precinct Model. The main high street of the first phase that is flanked by commercial, retail, and entertainment buildings. (Source: Author).

The grid system of roads that connect at multiple points to the surrounding areas facilitates integration with local, regional, and global catchments in what MacCormack (1994) described as the local and foreign transactions of successful urban places. The urban grid also provides a framework for a pedestrian scaled mixed-use area where attention to multiple uses (including residential) are located in close proximity along each street, and is considered vital to sustaining a vibrant community. Furthermore, the grid allows road traffic to be appropriately managed, basement parking is accessed from the minor streets, street parking is included to support active 'street life', and street intersections enable points of pedestrian crossing points.

The strategic placement of two significant public squares as focal points within the precinct 
is the crucial planning instrument that differentiates Melrose Arch as a development that encourages and supports vibrant urban life. Important to the success of the urban plan is the careful placement of local landmarks within the square and surrounding building form that recognises how the architecture is complaint to fundamentals set out in the urban design rationale where 'interest and intrigue are also enhanced by the use of significant elements that may form part of specific buildings' (US and MAPPS).
The concepts of continuity and legibility of building form are stressed through detailed building design codes that articulate how 'certain facades have an important topological role to play' (US and MAPPS). While all buildings are required to conform to the principles of the perimeter block that dictates a continuous streetscape to define the edges of the public domain, special architectural features were encouraged at strategic locations (Figure 6) within the precinct, while the other 'background' buildings require more modest treatment.

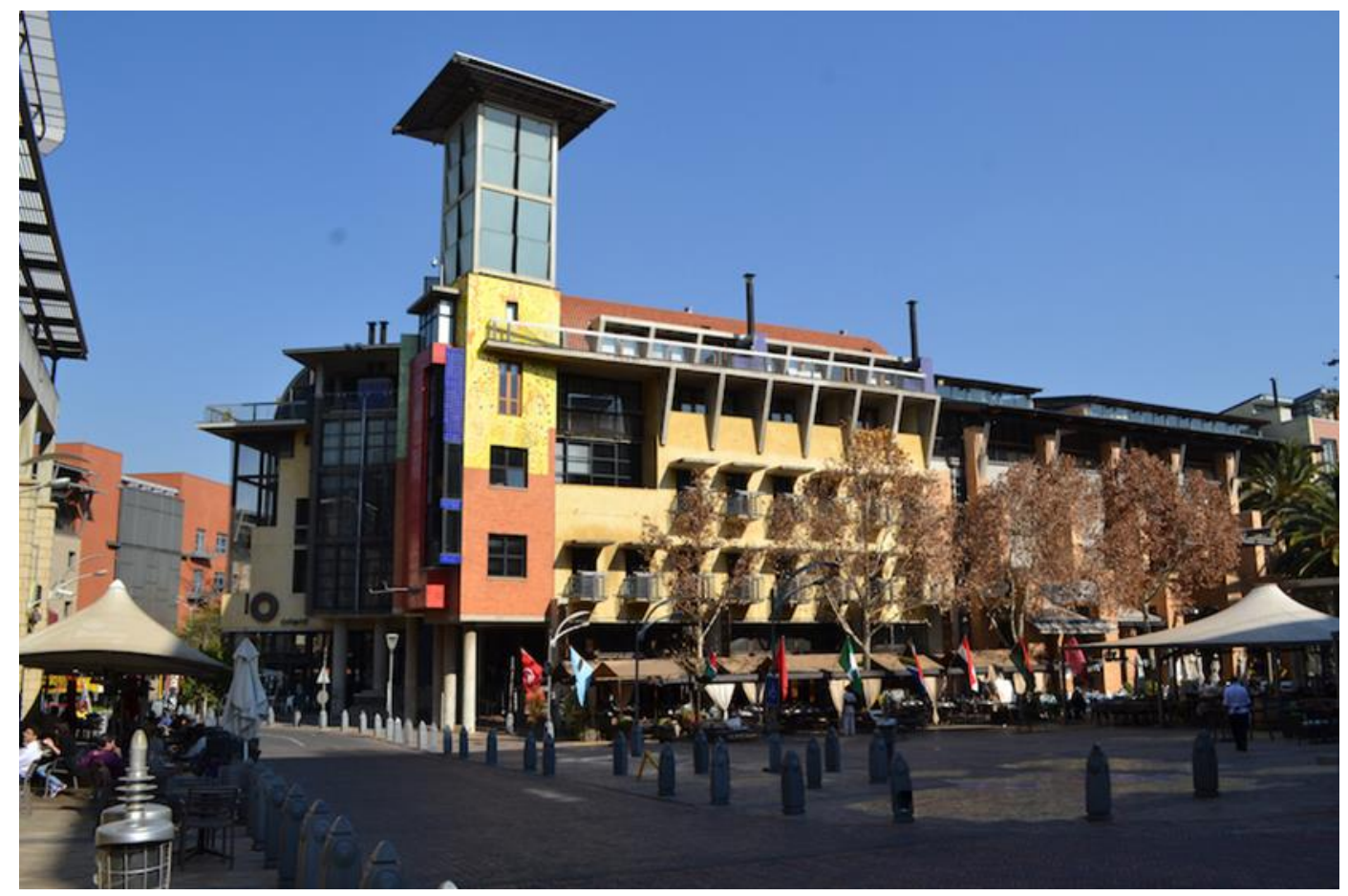

Figure 6. Melrose Arch. The main high street leads into one of the main squares with its place significance marked at the corner by the significant architectural feature of a mosaic tower. The pavement edges are activated by restaurant and cafe functions (Source: Lindy Burton).

Fundamental theory in urban morphology research has recognises the street and block plan within an established urban environment as being the most stable of the form complexes, it is the building utilisation that is the most prone to change (Conzen, 1960). Therefore, designing buildings that can accommodate this constant lifecycle flux is vital for the longevity of a development. Melrose Arch has adopted an appropriate approach of sustainability and robustness through understanding that 'Traditionally buildings in cities changed use and form whilst the public realm stayed constant and coherent. That combination of efficiency and flexibility can be created again without discouraging or delaying investment in the public spaces' (US and MAPPS). The important architectural strategies to support this approach are as follows: 
1. Structural flexibility is required, to accommodate various space needs and loadings.

2. Adaptability in façade element design is necessary. Entrances, fenestration, building signage, etc.

3. Ground floor areas adjoining public space must be occupied 'active' rather than passive uses.

4. 'Hard zones' (cores and services) must be located in plan so as not to restrict alternative uses of 'soft' (functional) areas.

5. Multiple entrances must be created to encourage interaction between public and private areas, and to improve planning adaptability.

6. Shallow plans must be built to maximize the use of natural lighting.

7. Privacy of ground floor activities. A level change between pavement and ground floor should be introduced. This serves the double function of reducing overlooking from outside while improving outlook from the inside.

8. Balconies on the public façade of all building types are required, as a means of allowing the private domain to interact with the public areas and to enhance surveillance of the public areas.

9. Ground floor apartments and offices should be entered directly from the public domain where possible, in order to enliven the building edge. (US and MAPPS)

Melrose Arch is one of largest new urban developments of its type, it demonstrates how urban design and architectural practice can effectively combine to achieve a high quality of built form that provides an environment to achieve the benefits of a traditional urban realm. Melrose Arch is however set within the complex context of the rapid urban change that has occurred in South Africa since democracy was achieved in 1994, and suffers from the perplexing dichotomies that pervade its society, social structures, and urban conditions. The development has attracted a range of criticism affected by the above and includes the physical determinism that underlies its generic urban model that derives from a New Urbanists assimilation of a European urban model, and despite the settlement morphology of nearby downtown Johannesburg being itself of Dutch colonial origin, it nevertheless could have provided a more salient template than that adopted for the masterplan.

\section{CONCLUSION}

An assessment of the performance of KGUV and Melrose Arch is considered against the ten ULI guidelines for Urban Villages that were listed earlier in the paper. It is evident from Table 1 that all attributes have been met by both projects.

Table 1. Assessment of KGUV and Melrose Arch against UDI ten development principles for successful urban villages.

\begin{tabular}{|l|l|l|l|}
\hline & ULI Principle & $\begin{array}{l}\text { KGUV } \\
\text { Attribute }\end{array}$ & $\begin{array}{l}\text { Melrose Arch } \\
\text { Attribute }\end{array}$ \\
\hline $\mathbf{1}$ & $\begin{array}{l}\text { Create an enduring } \\
\text { public realm. }\end{array}$ & $\begin{array}{l}\text { Active streets and parks/ lacks } \\
\text { central town square. }\end{array}$ & $\begin{array}{l}\text { Highly engaged street system, } \\
\text { and active public squares. }\end{array}$ \\
\hline $\mathbf{2}$ & $\begin{array}{l}\text { Respect market } \\
\text { realities. }\end{array}$ & $\begin{array}{l}\text { Uptake of development } \\
\text { opportunities. }\end{array}$ & $\begin{array}{l}\text { Uptake of development } \\
\text { opportunities }\end{array}$ \\
\hline
\end{tabular}




\begin{tabular}{|c|c|c|c|}
\hline 3 & $\begin{array}{l}\text { Share the risk; share the } \\
\text { reward. }\end{array}$ & $\begin{array}{l}\text { Partnership of State and } \\
\text { University, with private } \\
\text { interests. }\end{array}$ & $\begin{array}{l}\text { Private development led by } \\
\text { Pension Fund Investment. }\end{array}$ \\
\hline 4 & $\begin{array}{l}\text { Plan for development } \\
\text { and } \\
\text { complexity. }\end{array}$ & $\begin{array}{l}\text { Financing and ownership, } \\
\text { phasing strategies included. }\end{array}$ & $\begin{array}{l}\text { Primary initial investors } \\
\text { leading to phased strategy with } \\
\text { diversity of developers. }\end{array}$ \\
\hline 5 & Integrate multiple uses. & $\begin{array}{l}\text { Education, housing, retail, } \\
\text { community, health. }\end{array}$ & $\begin{array}{l}\text { Retail, commercial, residential, } \\
\text { entertainment. }\end{array}$ \\
\hline 6 & $\begin{array}{l}\text { Balance flexibility with } \\
\text { a long-term vision. }\end{array}$ & Enduring- buildings to last & Enduring- buildings to last \\
\hline 7 & $\begin{array}{l}\text { Capture the benefits that } \\
\text { density offers. }\end{array}$ & Lively 24 hour precinct. & inct. \\
\hline 8 & $\begin{array}{l}\text { Connect to the } \\
\text { community. }\end{array}$ & $\begin{array}{l}\text { Through accessibility of road } \\
\text { and footpath networks. }\end{array}$ & $\begin{array}{l}\text { Through accessibility of road } \\
\text { and footpath networks. }\end{array}$ \\
\hline 9 & Invest for sustainability. & ESD principles throughout. & ESD principles throughout. \\
\hline 10 & $\begin{array}{l}\text { Commit to intensive on- } \\
\text { site management. }\end{array}$ & $\begin{array}{l}\text { Well managed- incl. Sunday } \\
\text { Markets. }\end{array}$ & $\begin{array}{l}\text { Well managed- incl. public } \\
\text { events. }\end{array}$ \\
\hline
\end{tabular}

KGUV and Melrose Arch demonstrate that new approaches to collaboration are required for excellent urban outcomes to be achieved, irrespective of whether development is led by public or private interests. KGUV is an initiative of government and academic institution through a complex stakeholder partnership with private sector participation. Melrose Arch, on the other hand, stems from the instigation of a major private investment fund through property development, similarly with private sector participation and particular attention to multidiscipline consultant arrangements. In both cases, there has been a conscious attempt to avoid an overly large scale single building complex, in preference for breaking the overall development into small plot sizes that encourages participation of smaller scale construction and professional businesses, resulting in optimal diversity across the new urban neighbourhood. KGUV and Melrose Arch are master-planned with a street based structure that activates a pedestrian focused public realm with buildings that aggregate into an integrated precinct resonant of traditional urban form. The sustaining factors of workplace, recreation and dwelling throughout the developments are significant contributors to the overall quality of these new urban neighbourhoods. The complex organisational arrangements for stakeholder management in the case of KGUV, and multidiscipline collaboration at Melrose Arch, are crucial to underpin successful outcomes for Urban Villages.

Currently, the factors that regulate how a new large urban development can integrate into the broader town plan into which it is amalgamated have not been consistently applied; nor have the attributes for individual building design in relation to siting and adjacent buildings been adequately understood. These shortcomings have resulted in the under-achievement of too many new urban precincts. However, cases such as KGUV and Melrose Arch and other best practice exemplars demonstrate how a rigorous approach to city form based on traditional urban structures, when applied to townscape management, can result in excellent urban outcomes.

\section{REFERENCES}

BELL D \& JAYNE M. City of quarters: Urban villages in the contemporary city. Burlington, VT; Aldershot, England: Ashgate. 2004.

BERKE PR. Does Sustainable Development Offer a New Direction for Planning? Challenges 
for the Twenty-First Century. Journal of Planning Literature. 2002; 17(1): 21-36.

BOHL CC. Place making: Developing town centers, main streets, and urban villages. Washington, D.C: Urban Land Institute. 2002.

BRISBANE CITY COUNCIL (BCC). Brisbane City Plan 2000. Kelvin Grove Urban Village Local Plan. Brisbane: Brisbane City Council. 2000.

BYRNE J. Social housing, leadership and innovation, In Byrne, J., Chandler, B., \& Echberg, B. [Eds.] Urban Voices: Celebrating Urban Design in Australia. Urban Design Forum Incorporated, Melbourne, Vic. 2013.

CATALDI G. From Muratori to Caniggia: the origins and development of the Italian school of design typology. Urban Morphology. 2003; 7(1): 19-34.

CONZEN MRG. Alnwick, Northumberland a study in town-plan analysis. London: G. Philip \& Son. 1960.

FRANKLIN B \& TAIT M. Constructing an Image: The Urban Village Concept in the UK. Planning Theory. 2002; 1(3): 250-272.

GUPTA PK, TERZANO K \& URBAN LAND INSTITUTE. Creating great town centers and urban villages. Washington, DC: Urban Land Institute. 2008.

HECIMOVICH J. Reflections on Big City Zoning, Proceedings of the APA Conference. 2004. Accessed online on 01st May 2008 at http://www.planning.org/conferencecoverage/2 200/tuesday/reflections.htm

MacCORMAC R. Understanding transactions. Architectural Review. 1994; 194 (1165): 70-73.

McGLYNN S. \& SAMUELS I. The funnel, the sieve, and the template: towards an operational urban morphology. Urban Morphology. 2000; 4(2): 79-89.

MURRAIN P. Urban expansion: look back and learn, in Hayward, R. and McGlynn, S. [Eds.], Making better places: urban design now. Oxford: Butterworth-Heinemann. 1993; 83-94.

MURRAY C. Rethinking Neighbourhoods: From Urban Villages to Cultural Hubs, in BELL D \& JAYNE M. [eds.] City of quarters: urban villages in the contemporary city. Aldershot, Hants, England ; Burlington, VT : Ashgate. 2004.

PANCHOLI S, YIGITCANLAR T \& GUARALDA M. Public space design of knowledge and innovation spaces: learnings from Kelvin Grove Urban Village, Brisbane, Journal of Open Innovation: Technology, Market, and Complexity. 2015; 1: 13, 1-17.

QUEENSLAND UNIVERSITY OF TECHNOLOGY. Kelvin grove urban village master plan, Brisbane, Qld.: QUT. 2002.

QUEENSLAND UNIVERSITY OF TECHNOLOGY. Kelvin grove urban village: Integrated master plan, August 2004. Brisbane, Qld.: QUT. 2004.

SANDERS P. The rediscovery of traditional urbanism at Melrose Arch. SA Architect. January/ February. 2001; 50-55.

TALEN E \& ELLIS C. Beyond Relativism: Reclaiming the Search for Good City Form. Journal of Planning Education and Research. 2002; 22(1): 36-49.

UEHARA Y. Unknown Urbanity: Towards the Village in the City. Architectural Design. 2008; 78(5): 52-55. Accessed online on 11/07/2017 at http://onlinelibrary.wiley.com/doi/10.1002/ad.7 73/epdf.

US (URBAN SOLUTIONS \& PAUL MURRAIN) AND MAPPS. Melrose Arch 
Volume 10: Base Drawings and Design Guidelines. Mine Pension Funds Properties, Unpublished. 1998.

WARDNER P \& HEFFERAN M. Kelvin Grove Urban Village, Brisbane Post Implementation: Lessons for New Urbanism, Australasian Journal of Regional Studies. 2015; 21(3): 373397.

WOODS R. An environmentally sustainable development in Australia, PEB exchange Programme on Educational Building, No. 2003/18, OECD Publishing, Paris. 2003.

WOODS R \& HAMMONDS A. Kelvin Grove Urban Village -A Case Study Sustainability Response. Paper presented at ATEM/AAPPA Conference $\mathrm{E}=\mathrm{MC} 3$ Excellence = Managing Colleagues, Customers and Core Values. 2002. Accessed online on 22/05/2017 at http://www.tefma.com/uploads/assets/conferen co_papers/2002_AAPPA_Brisbane/042_Ruth\% 20Woods_paper.pdf.

WHITEHAND JWR. The making of the urban landscape, Oxford [England]; Cambridge, [Mass.]: Blackwell. 1992.

YAN M. Urban Villages. Architectural Design. 2008; 78(5): 56-59. Accessed online on $11 / 07 / 2017$ at http://onlinelibrary.wiley.com/doi/10.1002/ad.7 73/epdf.

YIGITCANLAR T, GUARALDA M, TABOADA M \& PANCHOLI S. Place Making for Knowledge Generation and Innovation: Planning and Branding Brisbane's Knowledge Community Precincts, Journal of Urban Technology. 2016; 23(1):115-146. 